\title{
Effect of Magnesium and Calcium as Spheroidizers on the Graphite Morphology in Ductile Cast Iron
}

\author{
Oluwole, O.O, Olorunniwo, O.E.,Ogundare, O.O., Atanda P.O. and Oridota, O.O \\ Materials Science and Engineering Department \\ Obafemi Awolowo University, Ile-ife, Nigeria
}

Corresponding author: Dr.O.Oluwole, leke_oluwole@yahoo.co.uk, Tel. +2348033899701

\begin{abstract}
This study investigated the effect of magnesium and calcium as spheroidizers on the graphite microstructure in cast iron. The cast iron samples were melted in an induction furnace with charge of known composition and, magnesium and calcium of known percentages were added as spheriodizers to the molten metal in the mould during the casting process. From the microstructure of the as- cast specimens it was observed that the use of $100 \% \mathrm{Mg}$ and a combined addition of $60 \%$ and $40 \%$ Ca as spheriodizers produced graphite spheroids instead of graphite flakes in the cast iron microstructure. The use of $100 \%$ Ca addition resulted in the production of graphite flakes in the specimen microstructure. The use of $80 \% \mathrm{Mg}$ and $20 \% \mathrm{Ca}$ resulted in the production of a chunky, stubby graphite microstructure, while the additions of 50\% $\mathrm{Mg}$ and $50 \% \mathrm{Ca}$, 40\% $\mathrm{Mg}$ and $60 \% \mathrm{Ca}$, and $20 \% \mathrm{Mg}$ and $80 \%$ Ca resulted in the microstructure having a flaky graphite microstructure.
\end{abstract}

Keywords: Spheroidizers, graphite, Morphology, Ductile Cast Iron

\section{INTRODUCTION}

The alloys of iron and carbon are the most important alloys in engineering applications. Steels and cast iron being the most important alloys of iron and carbon.

Cast iron is an alloy of Fe- C- Si with carbon content greater than $2.11 \%$ and is used in the as-cast state or after heat-treatment. Cast iron offers the Design Engineer a family of casting alloys that offers a virtually unique combinations of low cost with castability, strength, machinability, hardness, wear resistance, corrosion resistance, thermal conductivity, damping and availability. According to their use, cast irons may be categorized in two groups, namely, general and special purpose grades. The general- purpose grades include gray, white, malleable and spheriodal cast irons. These are used for most engineering applications. The special purpose cast iron called alloy cast iron is used in extreme heat, corrosion, and abrasion conditions. (Rajan et al, 1988)

The spheroidal iron was produced by adding small quantities of magnesium and cerium to a base cast iron with essentially the same analysis as grey cast iron, which produces graphite spheroids instead of flakes (Heine et al, 1976). 
Essentially, ductile cast iron consist of graphite spheroids dispersed in a matrix similar to that of steel with the graphite spheroids exerting only a minor influence on the mechanical properties in contrast to the effect of graphite flakes in gray iron. The matrix structure then has the greatest effect on the properties of the iron. Ductile irons are therefore a family of alloys, which combine the principle advantages of gray iron (low melting point, good fluidity and castability, excellent machinability, and good wear resistance) with the engineering advantages of steel ( high strength, toughness, ductility, hot workability and hardenability)

The production of ductile iron is $30-35 \%$ cheaper than steel and 3-4\% times cheaper than non-ferrous alloys and only $20-30 \%$ more costly than normal grey iron. Ductile iron finds application as a substitute for steel, malleable iron and non-ferrous alloys. When used in place of grey iron, the design of the casting is lighter. Ductile iron is used for producing steam engines block, axles, gears, some pistons for internal combustion engines, parts of agricultural machines, bearings, as well as parts of press chamber machines used for pressure die casting.

Ductile cast iron has excellent casting properties and machinability, which improves the production efficiency and reduces cost of production, whereas steel and malleable cast iron have poor casting properties and have to be machined from stock, which makes their production for small casting costly.

In this work, magnesium was added in the form of Ferro-silicon-magnesium alloy (Fe-Si$\mathrm{Mg}$ ) and $\mathrm{Ca}$ as pure calcium metal. The Fe-Si-Mg alloy and $\mathrm{Ca}$ were added in separate castings and then combined spheroidizers in varying quantities were added, and their effect on graphite morphology and degree of nodularisation were studied.

\section{MATERIALS AND METHODS}

\subsection{Liquid Metal Preparation}

Liquid iron metal was prepared by using the medium frequency induction furnace at Nigeria Machine Tools (NMT), Osogbo Nigeria. The furnace was charged with metallic materials to give base-iron with the following composition: C-3.5- 4.0\%, Si-2.8 - 3.0\%, Mn- $0.2-1.0 \%$, S- 0.01$0.03 \%$. The charge time to tap time was $1-2 \mathrm{~h}$ and the melt rate was $2-5 \mathrm{ton} / \mathrm{h}$. With tapping temperature of $1400-1500^{\circ} \mathrm{C}$.

\subsection{Charge Calculation}

The charge preparation for the cast iron composition given above was calculated. The charge consisted of cast iron scraps, mild steel scraps, carburizer and ferrosilicon. Spectrometric determination of the composition are given below in Table 1

\subsection{Making of Pattern}

The pattern made for the mould was a wooden rod of diameter $20 \mathrm{~mm}$ and length $500 \mathrm{~mm}$. The machines used for making the pattern include the wood saving and wood turning machine. The finishing operation was done by using sand paper of coarse and fine grade in that order. The pattern 
was then coated with wood varnish and then painted with pattern paint to enhance easy withdrawal from the mould. The pattern is a solid pattern.

Table 1: Composition of charges in percentage

\begin{tabular}{|l|l|l|l|l|l|}
\hline Charge & $\mathrm{C}$ & $\mathrm{Si}$ & $\mathrm{Mn}$ & $\mathrm{S}$ & $\mathrm{P}$ \\
\hline Cast iron scrap & 3.2 & 2.0 & 0.5 & 0.03 & 0.01 \\
\hline Mild steel scrap & 0.2 & 0.2 & 0.8 & 0.08 & 0.01 \\
\hline Carburiser & 99.93 & - & - & - & - \\
\hline Ferrosilicon & - & 75.0 & - & - & - \\
\hline
\end{tabular}

Table 2: Charge Calculation for two metric tons metals

\begin{tabular}{|l|l|l|l|l|l|l|l|}
\hline Charge & $\begin{array}{l}\text { Mass } \\
\text { Kg }\end{array}$ & $\%$ & C & Si & Mn & S & P \\
\hline Cast iron scrap & 1200 & 60 & 1.92 & 1.20 & 0.3 & 0.018 & 0.006 \\
\hline Mild steel scrap & 740 & 38.5 & 0.077 & 0.077 & 0.308 & 0.0308 & 0.0308 \\
\hline Carburiser & 30 & 1.5 & 1.499 & - & - & - & - \\
\hline Total & 2,000 & 100 & 34.496 & 1.277 & 0.608 & 0.0488 & 0.0099 \\
\hline
\end{tabular}

To balance $\mathrm{Si}$

Si required at tapping spout $=2.8 \% \mathrm{Si}$

Si in charge $=1.277 \%$

Deficiency of Si in charge $=2.8-1.276=1.523 \%$

Weight of deficient $\mathrm{Si}=0.01523 * 2000=30.48$

$1 \mathrm{Kg}$ of $\mathrm{Fe}-\mathrm{Si}$ contains $75 \% \mathrm{Si}$

Mass of Fe-Si required to give $30.48 \mathrm{Kg} / 0.75=40.64 \mathrm{Kg}$ of Fe-Si

Original Si in 2ton charge $=0.012 * 2000=25.54 \mathrm{Kg}$

Plus $\mathrm{Si}$ in $40.64 \mathrm{Kg} \mathrm{Fe}-\mathrm{Si}=30.48 \mathrm{Kg}$

Total Si in charge $=25.54+30.48=56.02 \mathrm{Kg}$

Therefore gross $\%$ of Si in charge $=(56.02 / 2000) * 100=2.8 \%$

\subsection{Making of Gating System}

The running and gating system is required to ensure that:

- The flow of metal should be as free as possible from turbulence but at a rate sufficient to avoid undue delay in filling the mould.

- Slag and oxidation dross within the iron are contained in the runner system and not allowed to enter the casting cavity

- Direct impingement of the metal stream on core or mould surfaces at a velocity sufficient to cause erosion of sand is avoided and

- The thermal gradients required to produce sound castings are established 
For a ductile iron casting a gating ration of $2: 2: 1$ is used, this is the relationship between the sectional area of the gate, runner, and sprue respectively. This describes a non-pressurized or sprue/runner control led system.

Calculation of the dimensions of different elements of the gating systems is as follows:

$\mathrm{G}=$ weight of the poured metal

$\mathrm{V}=$ volume of rod casting

From dimensions of the rod pattern

$\mathrm{D}$, diameter of rod $=20 \mathrm{~mm}$

$\mathrm{L}$, length of $\mathrm{rod}=500 \mathrm{~mm}$

Volume of rod casting $=$ cross sectional area $\mathrm{x}$ length

$$
=\pi \mathrm{D}^{2} \times \mathrm{L} / 4=157 \mathrm{~cm}^{3}
$$

Calculation of the filling time is based on Torocelli's equation. As the casting is entirely in the drag, the velocity at the gate is: $\mathrm{V}=\mathrm{C} \sqrt{ } 2 \mathrm{gh}_{\mathrm{s}}$

Where $\mathrm{C}=$ Coefficient of friction

$\mathrm{G}=$ acceleration due to gravity

$\mathrm{h}_{\mathrm{s}}=$ rated static head

And the flow rate through the gate, $\mathrm{F}$, = velocity $\mathrm{x}$ gate area

$$
\mathrm{F}=\mathrm{A}_{\mathrm{gc}} \sqrt{ } 2 \mathrm{gh}_{\mathrm{s}}
$$

However, the flow rate equals casting volume, $V_{d}$, divided by filling time, $t$. Hence

$$
\mathrm{T}=\mathrm{V}_{\mathrm{d}} / \mathrm{A}_{\mathrm{gc}} \sqrt{ } 2 \mathrm{gh}_{\mathrm{s}}
$$

But it has been established that the best average time to pour ductile iron is given by (Heine R.W et al, 1976):

Pouring time, $t=A \sqrt{ }$ pouring weight, $G$

Where pouring weight can be expressed mathematically as:

$\mathrm{G}=$ volume of rod casting $\mathrm{x}$ density

$\mathrm{G}=157 \times 7.8 \mathrm{~g} / \mathrm{cm}^{3}=1225 \mathrm{~g}=1.225 \mathrm{Kg}$

And $A=$ a coefficient with valve 1.7

Therefore, pouring time, $\mathrm{t}=1.7 \times 1.225=2.08 \mathrm{~s} \approx 2 \mathrm{~s}$

The calculated pouring time of $2 \mathrm{~s}$ is small due to the small weight of casting, however, for the sake of practicality; a pouring time of $4 \mathrm{~s}$ was used for the calculation.

From equ. $3, \mathrm{~A}_{\mathrm{gc}}=\mathrm{V}_{\mathrm{d}} / \mathrm{T} \sqrt{ } 2 \mathrm{gh}_{\mathrm{s}}$

Where acceleration due to gravity, $g=9.8 \mathrm{~cm}^{2} / \mathrm{s}$

Rated static head, $\mathrm{h}_{\mathrm{s}}=4.5 \mathrm{~cm}$ and assuming a friction factor of 0.7

$$
\mathrm{A}_{\mathrm{gc}}=157 /\left(4 \mathrm{X} 0.7 \sqrt{ }(2 \mathrm{X} 9.8 \mathrm{X} 4.5)=5.96 \mathrm{~cm}^{2}\right.
$$

Cross sectional area of gate $=5.96 \mathrm{~cm}^{2}$ 
For gating ratio of 1:1:2 for the cross sectional area of sprue, runner and gate respectively, we have: Cross sectional area of sprue $=2.98 \mathrm{~cm}^{2}$

Cross sectional of runner $=2.98 \mathrm{~cm}^{2}$

The sprue is tapered to prevent aspiration, that is the introduction of gases from the mould into the iron stream by a reduction in flow velocity, and to prevent slag from entering the mould such that $\mathrm{A}_{2} / \mathrm{A}_{1}=\left(\mathrm{h}_{2} / \mathrm{h}_{1}\right)^{1 / 2}$

Where $A_{2}=$ Cross sectional area of sprue top

$\mathrm{A}_{1}=$ Cross sectional of runner choke

$\mathrm{h}_{2}=$ depth of pouring cup

$\mathrm{h}_{1}=$ head of metal above the pouring time

To calculate area of choke from equation (4)

$\mathrm{A}_{2}=\left(\mathrm{h}_{1} / \mathrm{h}_{2}\right)^{1 / 2} \mathrm{~A}_{1}$

Where $\mathrm{h}_{1}=1 \mathrm{~cm}, \mathrm{~h}_{2}=3.5 \mathrm{~cm}, \mathrm{~A}_{1}=2.98 \mathrm{~cm}^{2}$

Therefore, $\mathrm{A}^{2}=(1 / 3.5)^{1 / 2}$ X $2.98=1.59 \mathrm{~cm}^{2}$

Cross sectional area of choke $=1.6 \mathrm{~cm}^{2}$

To calculate individual dimensions on the gating system,

2.4.1 For top sprue diameter, Ds; cross sectional area of sprue $=\pi \mathrm{Ds}^{2} / 4$

$$
\pi \mathrm{Ds}^{2} / 4=2.98 \mathrm{~cm}^{2}
$$

Therefore, $\mathrm{Ds}=$ Sprue diameter $=1.95 \mathrm{~cm} \approx 20 \mathrm{~mm}$

2.4.2 For choke runner diameter, Dc ; cross sectional area of choke $=\pi \mathrm{Dc}^{2} / 4$

Where $\pi \mathrm{Dc}^{2} / 4=1.6 \mathrm{~cm}^{2}$

$$
\mathrm{Dc}=\text { choke diameter }=1.43 \mathrm{~cm} \approx 15 \mathrm{~mm}
$$

\subsubsection{For runner width and thickness}

One of the main functions of the runner is to trap slag and prevent it from entering the mould and also to reduce turbulence; this depends on the horizontal surface of the runner. The horizontal area is increased by using a wide and thin runner of ratio 3:1 at the mid- length is used.

Therefore, width of runner $=28 \mathrm{~mm}$

Thickness of runner $=10 \mathrm{~mm}$

\subsubsection{For gate}

The level of iron in the runner rises so rapidly so that is well above the top of the gate before iron starts flowing through the gate, so the gate was thin and wide. A thickness to width ratio 1:3 was used.

Therefore thickness of gate $=10 \mathrm{~mm}$

Width of gate $=30 \mathrm{~mm}$

\subsubsection{Reaction chamber}

This chamber holds the granulate spheriodiser and allows a regular flow of liquid iron over it to promote immediate and uniform dissolution of the spheroidiser from the beginning to the end 
of pouring. A parameter referred to as the alloy solution factor is used to characterize this process requirement (Shea and Holtan, 1978). This factor is defined as the ratio of the pouring to the horizontal cross sectional area of the reaction chamber.

\subsection{Mould Preparation}

Moulding was done using the "all the sides" process. In this process, the drag part of the moulding box was filled with moulding sand and rammed with a pneumatic rammer and the top of the sand was then leveled off using smooth plywood. The rod pattern was then buried in the drag with only half of the pattern in the sand. The gate and runner part of the gating system were also buried in the sand with the gate in contact with the top of the rod to allow easy flow of the molten metal. Parting powder was then sprinkled on the sand for easy separation. The cope was then placed on the drag and the down sprue placed on the top of the reaction chamber. Sand was used to fill the box and then rammed. Care must be taken not to dislodge the down sprue. The cope and drag were then separated and the pattern and gating system removed. The cope and drag were closed and locating pins used to align the moulding boxes.

Seven moulding boxes were prepared, each with the same rod casting and same procedure as described above. Before closing the mould boxes, spheriodiser additions of measured quantity were placed in the reaction chamber cavity in the drag part of the mould and the mould was then closed and casting done.

\subsection{Spheriodizer Addition}

The two spheriodizers added were $5 \% \mathrm{Mg}-\mathrm{Fe}-\mathrm{Si}$ alloy and pure Ca metal (99.99\% purity) with composition of the alloy as follows:

\begin{tabular}{|l|l|l|l|l|l|l|}
\hline $\begin{array}{l}\text { Mg- } \\
\text { Ferrosilicon }\end{array}$ & $\mathrm{Si}$ & $\mathrm{Mg}$ & $\mathrm{Ca}$ & $\mathrm{Al}$ & $\mathrm{Fe}$ & \\
\hline $5 \%$ & $44.44 \%$ & $5 \%$ & $0.84 \%$ & $0.75 \%$ & $99.99 \%$ & \\
\hline
\end{tabular}

The spheriodizers were added in each mould labelled $A-G$ in the following composition

Mould A : 100\% Mg

For $0.05 \%$ residual $\mathrm{Mg}, 1 \%$ of $5 \% \mathrm{Mg}$ Ferrosilicon is used

$1 \%$ of $1.2 \mathrm{Kg}=12 \mathrm{~g}$ of $\mathrm{Fe}-\mathrm{Si}-\mathrm{Mg}$

This gives $100 \% \mathrm{Mg}$ as spheriodizer

Mould B : $100 \% \mathrm{Ca}$

Similarly, $1 \%$ of $\mathrm{Ca}$ inoculant is added for residual $\mathrm{Ca}$ and for inoculation of the cast iron

$1 \%$ of $1.2 \mathrm{Kg}=12 \mathrm{~g}$ of $\mathrm{Ca}$

This gives $100 \%$ of $\mathrm{Ca}$ as spheriodizer

Mould C: $80 \% \mathrm{Mg}$ and 20\% Ca

For a total spheriodizer addition of $12 \mathrm{~g}$

$80 \% \mathrm{Mg}$ of $12 \mathrm{~g}=9.6 \mathrm{~g}$ of $\mathrm{Fe}-\mathrm{Si}-\mathrm{Mg}$ alloy

$20 \% \mathrm{Ca}$ of $12 \mathrm{~g}=2.4 \mathrm{~g}$ of Ca metal 
Mould D : $60 \% \mathrm{Mg}$ and $40 \% \mathrm{Ca}$

$60 \% \mathrm{Mg}$ of $12 \mathrm{~g}=7.2 \mathrm{~g}$ of Fe- $\mathrm{Si}-\mathrm{Mg}$ alloy

$40 \% \mathrm{Ca}$ of $12 \mathrm{~g}=4.8 \mathrm{~g}$ of Ca metal

Mould E: 40\% $\mathrm{Mg}$ and $60 \% \mathrm{Ca}$

$40 \% \mathrm{Mg}$ of $12 \mathrm{~g}=4.8 \mathrm{~g}$ of $\mathrm{Fe}-\mathrm{Si}-\mathrm{Mg}$ alloy

$60 \% \mathrm{Ca}$ of $12 \mathrm{~g}=7.2 \mathrm{~g}$ of Ca metal

Mould F: 20\% $\mathrm{Mg}$ and $80 \% \mathrm{Ca}$

$20 \% \mathrm{Mg}$ of $12 \mathrm{~g}=2.4 \mathrm{~g}$ of $\mathrm{Fe}-\mathrm{Si}-\mathrm{Mg}$ alloy

$80 \% \mathrm{Ca}$ of $12 \mathrm{~g}=906 \mathrm{~g}$ of Ca metal

Mould G: $50 \% \mathrm{Mg}$ and 50\% Ca

This involved adding equal amount of $\mathrm{Fe}-\mathrm{Si}-\mathrm{Mg}$ and $\mathrm{Ca}$ metal to the cast iron. Therefore, $50 \%$ of $12 \mathrm{~g}=6 \mathrm{~g}$

This gives an addition of $6 \mathrm{~g}$ of $\mathrm{Fe}-\mathrm{Si}-\mathrm{Mg}$ and $6 \mathrm{~g}$ of $\mathrm{Ca}$ metal

\subsection{Microscopy}

The sample for micro examination were first cut into $125 \mathrm{~mm}$ and $9 \mathrm{~mm}$ thickness and demounted in bakelite to keep edges from getting round off and for better handling of the sample.

The mounted samples were then grinded on the series of silicon carbide grinding paper of increasing fineness: 240, 320, 400 and 600 respectively. After each grinding step, the sample is

rotated by $90^{\circ}$ to give good grinding finish and remove scratches from the grinding surface. Water is continuously added throughout the grinding operation to prevent grinded particles from becoming embedded between sample and grinding papers.

The samples were polished on a rotary wheel covered with fine selvyt cloth to remove the fine sscratches and give a smooth mirror like surface. The polishing cloth is impregnated with a polishing medium(Alumina),etched with $2 \%$ Nital and then dried with a clean tissue paper. Then the micrographs were taken.

\section{RESULTS AND DISCUSSION}

The addition of varying amounts of a Magnesium and Calcium to base cast iron with composition given above, through an in - mould spheroidisation technique, produces cast iron with different graphite morphology. The matrix in the cast iron was a pearlitic matrix due to the cooling rate of the cast sample. The samples were allowed to cool very slowly in the sand mould which resulted in the transformation of both eutectic and proeutectoid austenite by the eutectoid reaction to pearlite. 
In Fig. 1, magnesium was the sole spheroidiser used, the microstructure shows large irregular graphite nodules surrounded by ferrite in a pearlitic matrix. The presence of nodular graphite instead of flakes imparts favourable mechanical properties on the cast iron, such as high ductility, strength and toughness with good castability.

In Fig. 2, Calcium was the only spheroidizer used; the microstructure shows graphite flakes with dispersed and very isolated graphite nodules. This microstructure shows that calcium alone cannot be used as a spheroidizer. The presence of isolated nodules shows that the action of calcium as a deoxidizer and desulfurizer to promote nucleation of graphite nodules is not strong enough, hence, resulting in the formation of graphite flakes.

Fig. 3 shows the microstructure of an as-cast, cast-iron inoculated with $80 \% \mathrm{Mg}$ and $20 \%$ $\mathrm{Ca}$. This combined addition of alloys results in formation of nodular graphite with chunky, exploded graphite, which gives a compacted cast iron microstructure. As mentioned earlier, composition control is very important in the production of spheroidal cast iron and small changes in composition can result in a cast iron of different graphite morphology and hence, different physical properties.

Fig. 4 shows microstructure of an as- cast cast-iron inoculated with $60 \% \mathrm{Mg}$ and $40 \% \mathrm{Ca}$. This combined addition results in small regularly shaped nodules in pearlitic matrix. From this microstructure, the nodularity and hence, the dynamic modulus of elasticity can be determined. This sample gives the most favourable spheroidal cast iron production from a combined addition of calcium and magnesium.

Figs. 5, 6 and 7 show microstructure of samples inoculated with $40 \% \mathrm{Mg}$ and $60 \% \mathrm{Ca}, 20 \%$ $\mathrm{Mg}$ and $80 \% \mathrm{Ca}$, and $50 \% \mathrm{Mg}$ and $50 \% \mathrm{Ca}$ respectively. These microstructures have a high blend of mostly graphite flakes and graphite nodules showing that these inoculant compositions do not favour spheroidization. The inoculant mix of 40:60 Mg:Ca produced a high blend of graphite flakes with irregularly shaped and irregularly sized graphite nodules in a pearlitic matrix(Fig.5). The inoculant mix of 20:80 Mg:Ca produced a blend of high percentage graphite flakes with scanty irregularly shaped and irregularly sized graphite nodules in a pearlitic matrix(Fig.6) while the inoculant mix of 50:50 Mg:Ca mix produced a blend of graphite flakes with conglomerates of irregularly shaped and irregularly sized graphite nodules in a pearlitic matrix(Fig.7). 


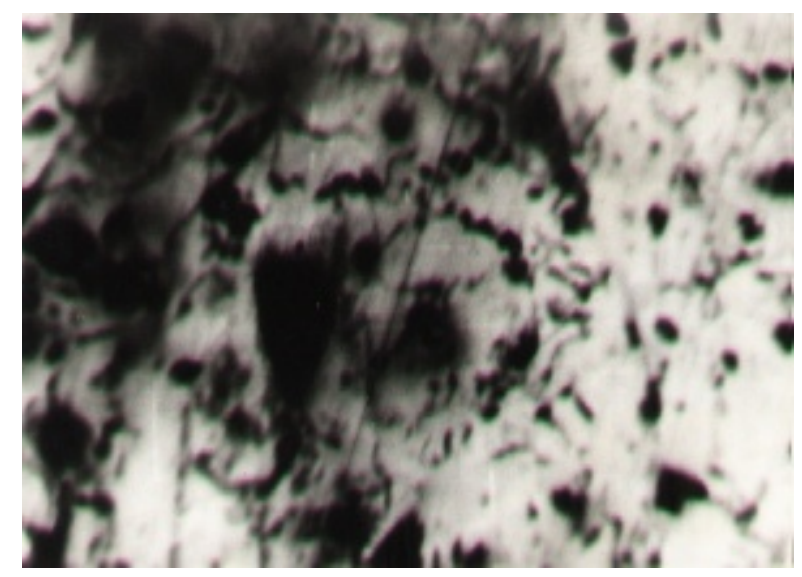

Fig. 1: Microstructure of as-cast, cast- iron inoculated with $100 \% \mathrm{Mg}$ showing irregularly shaped and irregularly sized graphite nodules in a pearlitic matrix(x100).

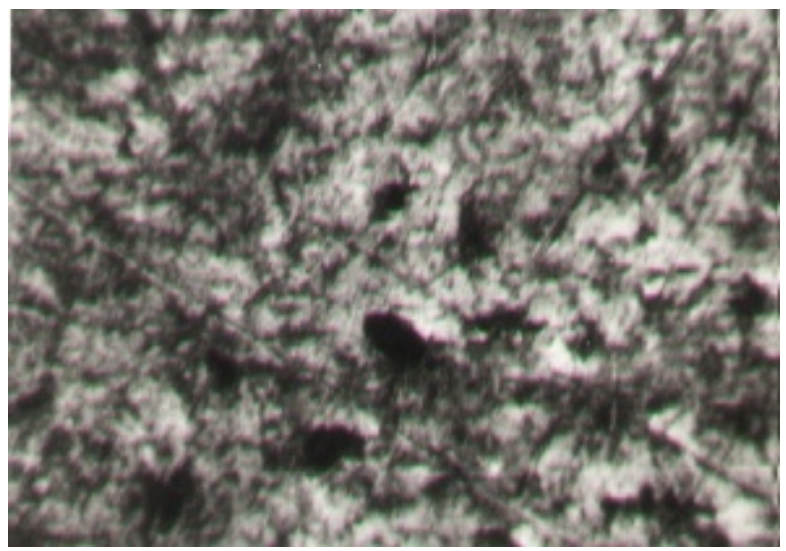

Fig. 2: Microstructure of as-cast, cast- iron inoculated with $100 \% \mathrm{Ca}$ showing graphite flakes with very sparsely distributed nodular graphite in a pearlitic matrix(x100). 


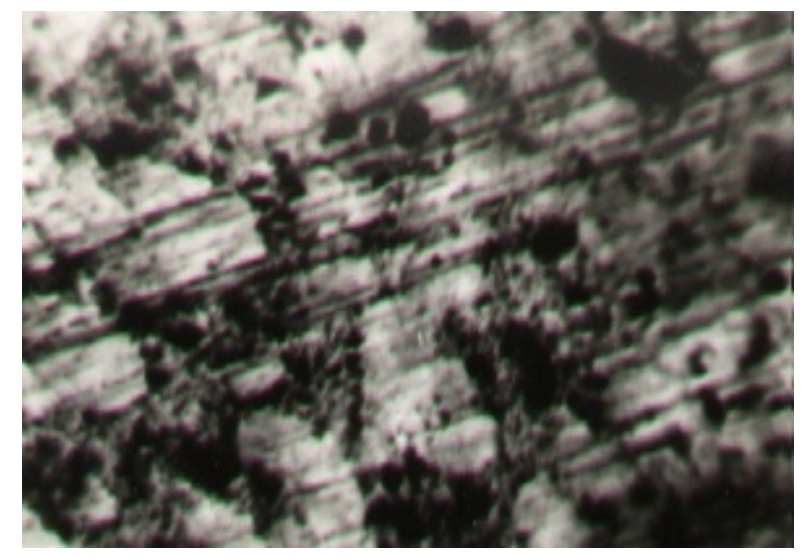

Fig. 3: Microstructure of as-cast, cast- iron inoculated with 80:20 Mg:Ca mix showing exploded graphite conglomerates in pearlitic matrix.(x100).

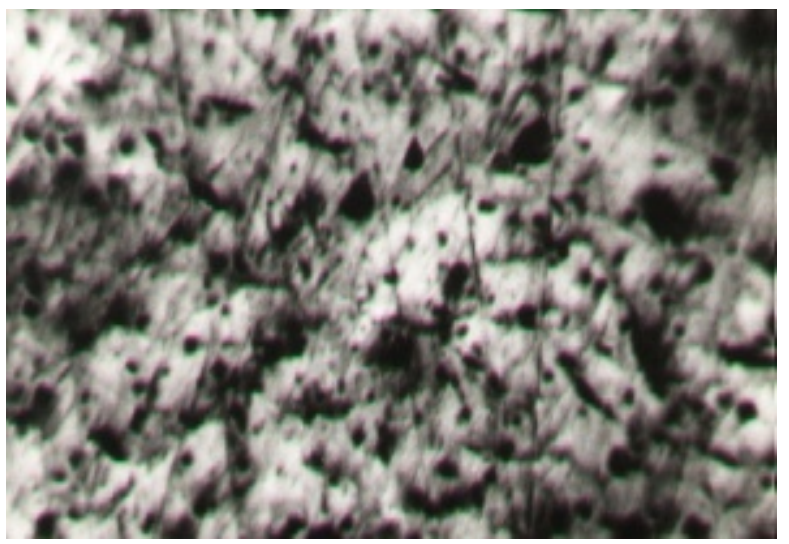

Fig. 4: Microstructure of as-cast, cast- iron inoculated with 60:40 Mg: Ca mix showing finely formed graphite nodules with sparsely dispersed graphite flakes in a pearlitic matrix.(x100). 


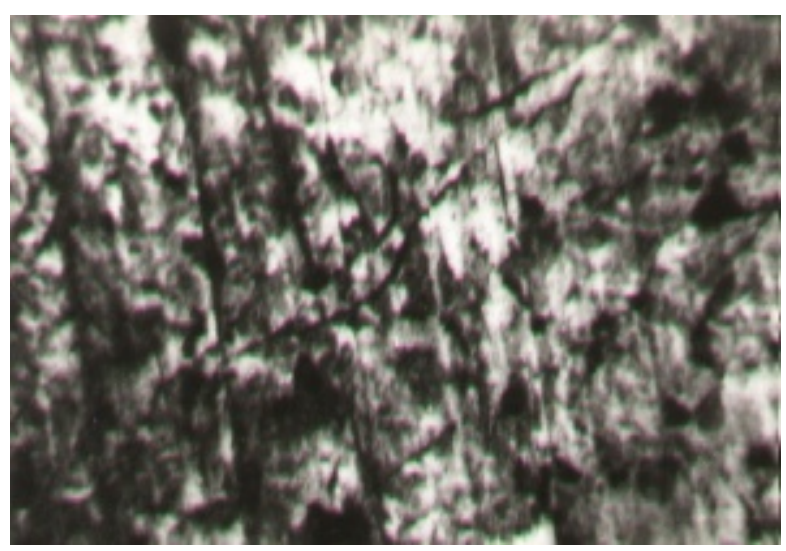

Fig. 5: Microstructure of as-cast, cast- iron inoculated with 40:60 Mg: Ca mix showing high blend of graphite flakes with irregularly shaped and irregularly sized graphite nodules in a pearlitic matrix.(x100).

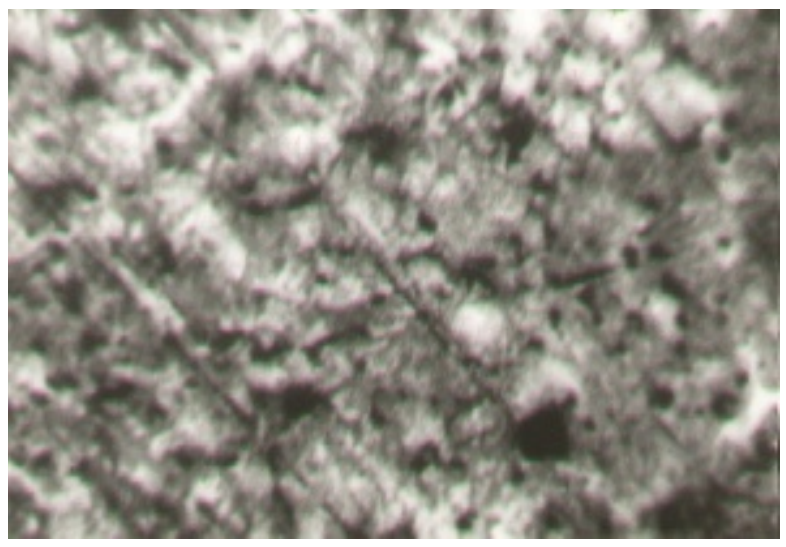

Fig. 6: Microstructure of as-cast, cast- iron inoculated with 20:80 Mg :Ca mix showing a blend of high percentage graphite flakes with scanty irregularly shaped and irregularly sized graphite nodules in a pearlitic matrix.(x100). 


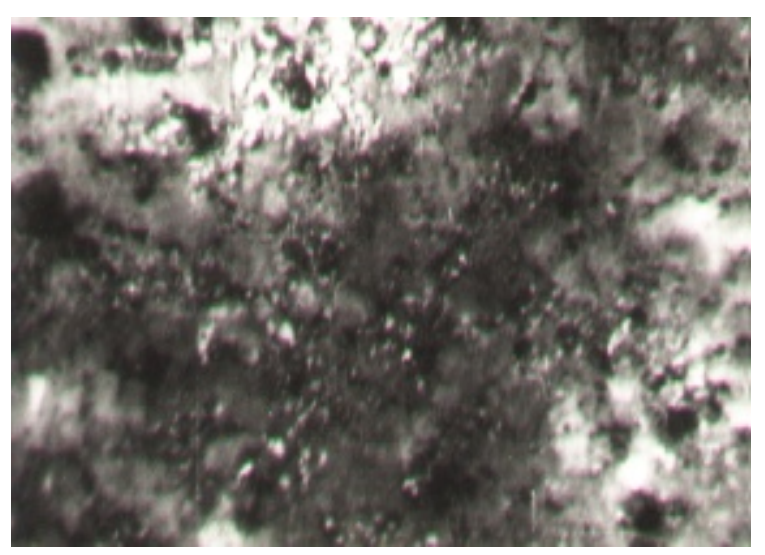

Fig. 7: Microstructure of as-cast, cast- iron inoculated with 50:50 Mg :Ca mix showing a blend of graphite flakes with conglomerates of irregularly shaped and irregularly sized graphite nodules in a pearlitic matrix.(x100).

\section{CONCLUSION}

On the strength of the results obtained from this research, the following conclusions were made:

(1) The use of magnesium as a spheroidizing agent produces spheriodal graphite cast iron having microscopic nodular graphite grains. These nodules have a minimum effect on the mechanical properties of the cast iron. The mechanical properties are mainly determined by the type of matrix structure and this imparts the favourable physical properties of cast iron (low melting point, good fluidity and castability), with the engineering advantages of steel (high strength, toughness, ductility, hot workability and hardenability).

(2) The use of calcium as a spheroidizing agent produces grey flake cast iron. The mechanical properties of the cast iron produced ar influenced by the graphite flakes.

(3) The use of a combined addition of $60 \% \mathrm{Mg}$ and $40 \% \mathrm{Ca}$ as spheroidizing agent in an inmould addition technique produces spheroidal graphite cast iron. This combined addition reduces the amount of $\mathrm{Mg}$ alloy used in the spheroidization process thereby reducing cost of production. The small shape of the nodule produced as shown in plate 4 also increases the nodularity of the cast iron.

(4) The use of other varying combined addition produces graphite flakes in the cast iron microstructure.

\section{REFERENCES}

1. Rajan T.V., Sharma C.P and Sharma, A. (1988): "Heat Treatment, Principles and Techniques, $1^{\text {st }}$ e. Prentice Hall, India.

2. Heine R.W., Coper C.R. and Rosenthal P.C (1976): "Principles of Engineering alloys", $2^{\text {nd }}$ ed. Tata Mcgraw - Hill, New Delhi 
3. Smith W.F., (1993): "Structure and properties of Engineering alloys", $2^{\text {nd }}$ ed. McGraw- Hill, New York

4. Sergeant G.F. and Evans E.R. (1978): "The production and properties of compacted graphite iron", Britian Foundryman, Vol 71,pg 115

5. Elliot R. (1988): “Cast iron Technology", $1^{\text {st }}$ ed. Butterworth, London

6. Landefeld C.F. (1980): "Thermochemistry of cast iron refractor reactions" American Foundry Society Transaction Vol. 88 pg 507

7. John V. B. (1992): "Introduction to Engineering Materials" $3^{\text {rd }}$ ed. Macmillian press Ltd, London

8. Dixon R.H.T and Hinchley D. (1984): “Ferrosilicon magnesium alloy development for the production of Spheroidized Graphite iron in 1983, Britian Foundryman, Vol 77 pg 5

9. Dawson J.V (1961), "Factors influencing the inoculation of cast iron”, BCIRA Journal Vol 9 pg 199

10. Walton C.F and Opar T.J. (1981): "Iron casting handbook covering data on Grey, Malleable and ductile iron, Iron casting Society Inc. New York

11. Davies D. J and Oleman L.A (1983) : “ The structure, Properties and Heat treatment of metals," Pitman books Ltd, London. 